\title{
GAMBARAN PENGETAHUAN DAN KUNJUNGAN IBU YANG MEMILIKI BALITA KE POSYANDU DI DESA CIDADALI KECAMATAN CIKALONG KABUPATEN TASIKMALAYA TAHUN 2012.
}

Oleh :

Tupriliany Danefi, SST

\section{A. Abstrak}

Posyandu sebagai wahana alih informasi dan teknologi dari petugas kesehatan kepada masyarakat, pada masa krisis ekonomi keberadaannya kurang menggembirakan (Depkes RI, 2001). Berdasarkan studi pendahuluan, didapatkan adanya penurunan jumlah kunjungan peserta Posyandu di Desa Cidadali Kecamatan Cikalong Kabupaten Tasikmalaya dari 544 orang menurun menjadi 104 orang bulan Pebruari 2011. Tujuan penelitian ini adalah Untuk mengetahui gambaran pengetahuan dan kunjungan ibu yang memiliki balita ke posyandu di Desa Cidadali Kecamatan Cikalong Kabupaten Tasikmalaya tahun 2012.

Jenis penelitian yang digunakan adalah kuantitatif dengan metode deskriptif. Populasi dalam penelitian ini adalah seluruh ibu yang mempunyai balita di Desa Cidadali Kecamatan Cikalong Kabupaten Tasikmalaya tahun 2012. Jumlah populasi dalam penelitian ini adalah 540 orang. Tehnik pengambilan sampel adalah simpel random sampling sehingga didapatkan semua ibu yang mempunyai balita sejumlah 63. Dalam penelitian ini menggunakan Analisa univariat dilakukan untuk mendeskripsikan variabel pengetahuan dan kunjungan ibu yang memiliki balita ke posyandu.

Hasil penelitian didapatkan bahwa tingkat pengetahuan ibu tentang posyandu di Desa Cidadali Kecamatan Cikalong Kabupaten Tasikmalaya tahun 2012 sebagian besar termasuk kategori kurang. Serta tingkat kunjungan balita ke posyandu di Desa Cidadali Kecmatan Cikalong Kabupaten Tasikmalaya tahun 2012 sebagian besar termasuk kategori tidak pernah.

Saran yang direkomendasikan adalah instansi kesehatan dapat meningkatkan fasilitas pelayanan di posyandu sehingga masyarakat dapat merasakan manfaat pelayanan dasar bagi masyarakat.

Kata Kunci : Posyandu, pengetahuan ibu, kunjungan 


\section{B. Latar Belakang}

Pembangunan kesehatan saat ini diarahkan untuk semakin meningkatkan kualitas sumber daya manusia dan pemerataan jangkauan pelayanan kesehatan termasuk perbaikan gizi, percepatan penurunan angka kematian bayi, anak balita, ibu hamil dan ibu bersalin yang dikembangkan melalui peran serta masyarakat. Salah satu bentuk upaya yang dilakukan secara terpadu pada tingkat Desa atau Rukun Warga dan diwujudkan dalam bentuk Pos Pelayanan terpadu atau Posyandu (Depkes RI, 2001).

Posyandu sebagai wahana alih informasi dan teknologi dari petugas kesehatan kepada masyarakat, pada masa krisis ekonomi keberadaannya kurang menggembirakan (Depkes RI, 2001). Kesehatan anak yang berusia dibawah 5 tahun (Balita) merupakan modal dasar dalam pembangunan negeri kini. Betapa penting setiap keluarga untuk menjaga keluarganya agar terhindar dari berbagai penyakit, termasuk kekurangan gizi karena gizi yang baik menentukan kualitas para kader bangsa di masa yang akan datang (Depkes RI, 2000).

Data Dinas Kesehatan Kabupaten Tasikmalaya tahun 2011 jumlah cakupan SKDN (Sasaran KMS ditimbang naik) yang meliputi partisipasi masyarakat D/S (Balita ditimbang/sasaran) sebesar 54,5\% sedangkan target yang ditetapkan adalah $80 \%$. Menurut laporan hasil kegiatan tahunan program Kesehatan Ibu dan Anak - Keluarga Berencana kesehatan Desa Cidadali Kecamatan Cikalong Kabupaten Tasikmalaya tahun 2011, dimana pencapaian target kunjungan ibu yang mempunyai balita dengan sasaran yang ada (jumlah bayi dan anak balita yang ada) ternyata pencapaian target D/S tahun 2011 masih rendah yaitu 45,5\% sedangkan target yang telah ditetapkan adalah $60 \%$. Dari capaian cakupan program diatas menunjukan tingkat partisipasi masyarakat khususnya penimbangan balita belum mencapai $80 \quad \%$ (Dinkes Kabupaten Tasikmalaya, 2009).
Berdasarkan studi pendahuluan, didapatkan adanya penurunan jumlah kunjungan peserta Posyandu di Desa Cidadali Kecamatan Cikalong Kabupaten Tasikmalaya dari 544 orang menurun menjadi 104 orang bulan Pebruari 2011. Disamping itu dari 10 orang warga yang diwawancarai secara acak tentang peran dan fungsi Posyandu, didapatkan sebagian besar tidak mengetahui program kerja yang dimiliki Posyandu serta jenis pelayanan kesehatan yang dapat diberikan oleh Posyandu (Profil Puskesmas Cikalong, 2011). Hal ini terbukti bahwa salah satu faktor yang mempengaruhi kunjungan balita ke posyandu yaitu predisposisi, adalah pengetahuan (Harbandiyah, 2006). Faktor pengetahuan masyarakat yang baik mempunyai pengaruh yang besar terhadap peningkatan status kesehatan seseorang, sedangkan pengetahuan masyarakat yang buruk dapat menyebabkan kegagalan dalam peningkatan status kesehatannya (Budiman, 2004). Faktor - faktor yang berhubungan terhadap kunjungan balita ke posyandu adalah faktor umur balita, tenaga penolong persalinan, kemampuan membaca, jumlah anak, status pekerjaan ibu, ketersediaan waktu ibu untuk merawat anak.

Berdasarkan latar belakang diatas, maka penulis bermaksud untuk melakukan penelitian yang berjudul tentang "Gambaran pengetahuan dan kunjungan ibu yang memiliki balita ke posyandu di Desa Cidadali Kecamatan Cikalong Kabupaten Tasikmalaya tahun 2012"

Tujuan penelitian ini adalah Untuk mengetahui gambaran pengetahuan dan kunjungan ibu yang memiliki balita ke posyandu di Desa Cidadali Kecamatan Cikalong Kabupaten Tasikmalaya tahun 2012. Manfaat penelitian ini sebagai bahan masukan bagi instansi dalam upaya peningkatan kunjungan balita (D/S) ke posyandu dan monitoring kegiatan Program Kesehatan Ibu dan Anak Keluarga Berencana kesehatan. 


\section{Metode}

Jenis penelitian yang digunakan adalah kuantitatif dengan metode deskriptif. Populasi dalam penelitian ini adalah seluruh ibu yang mempunyai balita di Desa Cidadali Kecamatan Cikalong Kabupaten Tasikmalaya tahun 2012. Jumlah populasi dalam penelitian ini adalah 540 orang. Tehnik pengambilan sampel adalah simpel random sampling sehingga didapatkan semua ibu yang mempunyai balita sejumlah 63 .

Instrumen yang digunakan dalam penelitian ini adalah berupa kuesioner yang dibuat sendiri oleh peneliti.

Pengolahan Data

\section{Editing Data}

Merupakan tahap kegiatan mengoreksi data yang terkumpul baik cara pengisian, kesalahan pengisian dari setiap jawaban yang teradpat pada kuesioner.

\section{Coding Data}

Merupakan tahap kegiatan memberi kode setiap jawaban yang diberikan

\section{Hasil Penelitian}

\section{Analisis Univariat}

a. Responden Berdasarkan Tingkat Pengetahuan Tentang Posyandu

\section{Tabel 3.9 Distribusi Responden berdasarkan Tingkat Pengetahuan}

\begin{tabular}{cll}
\hline Pengetahuan & Jumlah & \% \\
\hline Baik & 19 & $30,2 \%$ \\
\hline Cukup & 15 & $23,8 \%$ \\
\hline Kurang & 29 & $46 \%$ \\
\hline Jumlah & 63 & $100 \%$ \\
\hline
\end{tabular}

Berdasarkan tabel 3.9 diketahui bahwa pengetahuan responden sebagian besar termasuk kategori kurang yaitu sebanyak 29 orang (46\%) tentang pertanyaan pengetahuan posyandu dan yang termasuk kategori baik sebanyak 19 orang $(30,2 \%)$ tentang prtanyaan KB. 
b. Kunjungan Balita ke Posyandu

Tabel 4.0 Distribusi Kunjungan Balita ke Posyandu di Desa Cidadali

\begin{tabular}{lll}
\hline $\begin{array}{l}\text { Kunjungan } \\
\text { Balita ke } \\
\text { Posyandu }\end{array}$ & Jumlah & \% \\
\hline Sering & 17 & $27,0 \%$ \\
\hline Jarang & 19 & $30,2 \%$ \\
\hline $\begin{array}{l}\text { Tidak } \\
\text { Pernah }\end{array}$ & 27 & $42,9 \%$ \\
\hline Jumlah & 63 & $100 \%$ \\
\hline
\end{tabular}

Berdasarkan tabel 4.0 diketahui bahwa responden yang tidak pernah datang ke Posyandu sebanyak 27 orang (42,9\%), dan yang jarang datang sebanyak 19 orang $(30,2 \%)$.

\section{E. Pembahasan}

Berdasarkan hasil penelitian yang dilakukan terhadap 63 responden yang memiliki balita dan kunjungan balita ke posyandu, maka dilakukan pembahasan sebagai berikut :

1. Tingkat Pengetahuan

Berdasarkan hasil penelitian dapat diketahui bahwa responden yang memiliki balita dan kunjungan balita ke posyandu, sebagian besar mempunyai pengetahuan yang kurang yaitu sebanyak 29 orang $(46,0 \%)$. Dari hasil tersebut, peneliti berpendapat bahwa pengetahuan dapat mempengaruhi responden untuk membawa balitanya berkunjung ke posyandu. Selain itu juga, responden mengetahui manfaat dan tujuan mengikuti kegiatan posyandu. Hal ini dapat dilihat pada hasil jawaban responden yang hampir semua responden dapat menjawab dengan benar mengenai tujuan dari kegiatan posyandu.

Menurut Bloom yang dikutip oleh Notoatmodjo (2003) pengetahuan adalah pemberian bukti seseorang melalui proses pengingatan atau pengenalan informasi, ide yang sudah didapat sebelumnya. Pengetahuan akan membentuk sikap dan selanjutnya niat untuk melakukan tindakan yang salah satunya dapat memjpengaruhi kunjungan ibu yang mempunyai balita untuk berkunjung ke posyandu untuk memeriksakan anak balitanya. Perilaku dimulai dari domain kognitif (pengetahuan), dalam arti subjek tahu terlebih dahulu terhadap stimulus yang berupa materi atau subjek sehingga menimbulkan respon batin dalam bentuk sikap terhadap objek yang diketahuinya. Akhirnya rangsangan yakni objek yang sudah diketahui dan didasari sepenuhnya tersebut akan menimbulkan respon lebih jauh lagi yaitu berupa tindakan (action) terhadap stimulus tadi.

Peningkatan pengetahuan sendiri tidak selalu menyebabkan terjadinya suatu perubahan akan tetapi ada hubungan yang positif yang berkaitan dengan perubahan tindakan. Tindakan tersebut mungkin tidak dapat berubah secara la ngsung sebagai respon terhadap kesadaran ataupun pengetahuan tapi efek komulatif dari peningkatan kesadaran, pengetahan berkaitan dengan nilai, keyakinan, kepercayaan, minat dalam bertindak.

Berdasarkan data hasil penelitian dapat diketahui penduduk desa cidadali mayoritas berpendidikan tamatan SD, yaitu sebanyak 2836 orang atau 70,34\% dan sebagian besar bermata pencaharian sebagai petani yaitu 3138 orang atau 78,94\% dan dilihat dari keadaan geografis Desa Cidadali sebagian besar merupakan daerah pegunungan dan pesawahan tadah hujan sehingga masih terdapat daerah yang sulit dijangkau oleh kendaraan roda dua atau kendaraan roda empat.

Hal ini didukung dengan pendidikan responden yang mayoritas berpendidikan tamat SD. Selain itu juga, pengetahuan 
yang diperoleh responden hanya didapat dari pengalamannya sendiri, ini diakibatkan karena tingkat pengahasilan yang diperoleh tidak memadai dan tidak adanya keinginan untuk melanjutkan sekolah kejenjeng yang lebih tinggi sehingga mayoritas rsponden memiliki pengetahuan yang rendah.

2. Kunjungan Balita ke Posyandu

Berdasarkan hasil penelitian dapat diketahui bahwa kunjungan balita ke posyandu sebagian besar masih termasuk dalam kategori tidak pernah yaitu sebanyak 27 (42,9\%). Dari hasil tersebut diatas peneliti berpendapat bahwa tinggi rendahnya kesadaran ibu yang mempunyai balita dapat mempengaruhi untuk meningkatkan kunjungan balita ke posyandu. Karena melalui kunjungan balita ke posyandu akan mendapatkan informasi

\section{F. Simpulan dan saran}

Berdasarkan hasil penelitian dan pembahasan, maka penulis dapat menyimpulkan bahwa :

1. Tingkat pengetahuan ibu tentang posyandu di Desa Cidadali Kecamatan Cikalong Kabupaten Tasikmalaya tahun 2012 sebagian besar termasuk kategori kurang.

\section{G. Referensi}

Elis Ernawati, (2011), Skripsi : "Hubungan Pengetahuan Ibu Yang Mempunyai Balita Terhadap Keaktifan Femanfaatan Kegiatan Posyandu Di Desa Pyspajaya Kecamatan Puspahiang Kabupaten Tasikmalaya Periode Agustus - September 2011".

Arikunto, (2003). Prosedur Penelitian. Jakarta : PT. Rineka Cipta. Jakarta.

Depkes RI, 2000. Buku Kader Posyandu. Jakarta.

Depkes RI, 2001. Buku Pedoman Petugas Lapangan. Jakarta : Komite Nasional Posyandu. Jakarta.

Dinkes Kabupaten Tasikmalaya, 2009. Profil Dinas Kesehatan Kabupaten Tasikmalaya. Tasikmalaya. yang lebih mudah sehingga akan lebih memahami tentang pentingnya perumbuhan dan perkembangan balita.

Berdasarkan analisis peneliti dapat dijabarkan bahwa yang mempengaruhi terhadap kunjungan balita ke posyandu adalah salah satunya kurangnya kesadaran ibu yang mempunyai balita terhadap pentingnya kegiatan posyandu juga kurangnya dukungan dari keluarga khususnya suami akan pentingnya kegiatan posyandu serta letak geografis dimana sebagian besar tempat tinggal penduduk di Desa Cidadali terletak di pegunungan dan sulit dijangkau oleh kendaraan ditambah penghasilan penduduk yang mayoritas buruh/tani sehingga sulit memahami akan pentingnya kegiatan posyandu.

2. Tingkat kunjungan balita ke posyandu di Desa Cidadali Kecmatan Cikalong Kabupaten Tasikmalaya tahun 2012 sebagian besar termasuk kategori tidak pernah.

Saran yang direkomendasikan adalah instansi kesehatan dapat meningkatkan fasilitas pelayanan di posyandu sehingga masyarakat dapat merasakan manfaat pelayanan dasar bagi masyarakat.

Effendi, Nasrul. 1998. Dasar - dasar Keperawatan Kesehatan Masyarakat.

Notoatmodjo, 2003. Pendidikan dan Perilaku Kesehatan, Jakarta. PT. Asdi Mahasatya.

Notoatmodjo, S. 2002. Metodologi Penelitian Kesehatan, Edisi Refisi, Jakarta. Rineka Cipta.

Therstone, A 1999. Revitalisasi Posyandu. http://www.usu.ac.id diakses tahun 2011.

Zulkifli, (2005). Posyandu dan Kader Kesehatan, http://www.library.usu.ac.id diakses tahun 2011. 